TARNOWSKIE STUDIA TEOLOGICZNE 36 (2017) NR 1, S. 5-20

http://dx.doi.org/10.15633/tst.2321

ks. Janusz Królikowski ${ }^{1}$

UNIWERSYTET PAPIESKI JANA PAWŁA II W KRAKOWIE

\title{
Jak powstała Wulgata i któremu tekstowi Pisma Świętego przysługuje to miano?
}

Wulgata jest łacińską wersją Pisma Świętego, która w Kościele cieszy się szczególnym szacunkiem² ${ }^{2}$ posiada wciąż pierwszorzędne znaczenie, zwłaszcza w liturgii. Zarazem jednak panuje w odniesieniu do Wulgaty wiele nieporozumień i w mówieniu o łacińskich tekstach Biblii popełnia się ewidentne błędy, nazywając Wulgatą to, co nią w żadnym razie nie jest. Dowodzi tego choćby częste używanie zwrotu „Wulgata św. Hieronima” czy też nadawanie miana „Wulgaty” (W pisane dużą literą) łacińskim tekstom Biblii, gdy określenie tego typu nie było jeszcze nazwą własną. W tym duchu ks. Krzysztof Bardski w Encyklopedii katolickiej zdefiniował Wulgatę tymi słowami: „wersja Pisma Świętego zrewidowana przez Hieronima na polecenie papieża Damazego I"3. Na linii tej interpretacji sytuuje się także

Ks. dr hab. Janusz Królikowski - profesor Uniwersytetu Papieskiego Jana Pawła II w Krakowie, od roku 2014 dziekan Wydziału Teologicznego Sekcja w Tarnowie Uniwersytetu Papieskiego Jana Pawła II w Krakowie. W latach 1991-1996 studiował teologię na uczelniach rzymskich: Papieskim Uniwersytecie Świętego Krzyża (doktorat 1995), Papieskim Instytucie Wschodnim, Instytucie Św. Tomasza przy Uniwersytecie „Angelicum”. W roku 2003 habilitował się w zakresie teologii dogmatycznej w Papieskiej Akademii Teologicznej w Krakowie. W latach 1996-2009 wykładał teologię na Papieskim Uniwersytecie Świętego Krzyża w Rzymie, a od roku 1997 wykłada teologię dogmatyczną na Wydziale Teologicznym Sekcja w Tarnowie. Od roku 2010 wykładowca mariologii w Instytucie Maryjno-Kolbiańskim „Kolbianum” w Niepokalanowie. Członek Polskiego Towarzystwa Mariologicznego, Towarzystwa Teologów Dogmatyków, Polskiego Towarzystwa Teologicznego Oddział w Tarnowie, członek zwyczajny Międzynarodowej Papieskiej Akademii Maryjnej w Rzymie.

${ }^{2}$ Zob. II Sobór Watykański, Konstytucja dogmatyczna o objawieniu Bożym Dei Verbum, nr 22.

3 K. Bardski, Wulgata, w: Encyklopedia katolicka, red. E. Giglewicz, t. 20, Lublin 2014, kol. 1027. 
wydanie Dokumentów soborów powszechnych w Wydawnictwie wam pod redakcją ks. Arkadiusza Barona i ks. Henryka Pietrasa. W tomie obejmującym dokumenty Soboru Trydenckiego, tytuł drugiej części słynnego dekretu Sacrosancta z czwartej sesji ( 8 kwietnia 1546 r.), przetłumaczono w taki sposób: „Przyjęcie wydania biblii zwanej Wulgatą oraz o sposobie interpretacji Pisma Świętego" (Recipitur vulgata editio bibliae praescribiturque modus interpertandi sacram scripturam $)^{4}$. Konsekwencją tak przetłumaczonego tytułu jest potem zaproponowane w dalszym tekście tłumaczenie zdania: „potissimum vero haec ipsa vetus et vulgata editio quam emendatissime imprimatur”, jako: „aby [...] zwłaszcza stare wydanie Wulgaty było jak najstaranniej drukowane"s.

Są to anachronizmy, które wynikają przede wszystkim ze słabej znajomości dziejów tekstu Pisma Świętego. Mogą wywoływać wiele zamętu także w teologii, zwłaszcza gdy sięga się do starych cytowań biblijnych, dokonując niejednokrotnie ich niepoprawnej korekty lub gdy po prostu „naciąga się" interpretacje teologiczne, które opierają się na innych wersjach tekstu biblijnego niż powszechnie przyjęte. Warto więc przyjrzeć się, jak powstała Wulgata i któremu tekstowi Pisma Świętego przysługuje to utrwalone w języku Kościoła i teologii miano. Aby dojść do ściślejszych konkluzji w tej materii, trzeba przyjrzeć się bardzo dynamicznym, w tym także naznaczonym kontrowersjami, dziejom Biblii w okresie reformacji katolickiej, zwłaszcza w czasie soboru trydenckiego i bezpośrednio po nim, na pierwszym etapie realizacji sformułowanych w czasie jego obrad wskazań ${ }^{6}$.

\section{Kanon biblijny}

Aby wyjaśnić powstanie Wulgaty, trzeba najpierw sięgnąć do wypowiedzi na temat Pisma Świętego, które zawdzięczamy Soborowi Trydenckiemu ${ }^{7}$. Jednym z pierwszych postanowień tego soboru było podanie

\footnotetext{
4 Sobór Trydencki, Dekret Sacrosancta II, w: Dokumenty soborów powszechnych, tekst łaciński, polski, t. 4: (1511-187o) Lateran V-Trydent-Watykan I, układ i opracowanie A. Baron, H. Pietras, Kraków 2004, s. 212-213.

5 Sobór Trydencki, Dekret Sacrosancta II, s. 214-215.

6 Por. G. Bedouelle, La Réforme catholique, w: Le temps des Réformes et la Bible, direct. G. Bedouelle, B. Roussel, Paris 1989, s. 327-367.

7 Na temat twórców tej wypowiedzi por. A. Vaccari, Esegesi ed esegeti al Concilio di Trento, „Biblica” 27 (1946) no. 4, s. 320-337.
} 
ostatecznego - kanonicznego - wykazu ksiąg świętych Starego i Nowego Testamentu. Taki punkt wyjścia debaty soborowej miał zarówno wymiar symboliczny - ojcowie chcieli podkreślić, że Biblia jest ich duchową ojczyzną - jak i wymiar duchowo-doktrynalny, a mianowicie zwracali za jego pośrednictwem uwagę, że w ich rozstrzygnięciach doktrynalnych odzwierciedla się tylko wiara biblijna, którą interpretują odpowiednio do wymagań czasów i stawianych pytań. Do tego zagadnienia nie powrócono już w trakcie obrad soborowych, co nie oznacza bynajmniej, że debata teologiczna na temat Pisma Świętego została definitywnie zamknięta. Sobór dokonał tylko jej wyraźnego ukierunkowania, co w krótkim czasie wydało bogate owoce, z których korzystamy do dnia dzisiejszego, najczęściej o tym niewiele wiedząc.

W wypowiedzi Soboru Trydenckiego przyjęto więc integralnie i dosłownie kanon Soboru Florenckiego, który został ogłoszony 4 lutego 1442 roku w Bulli unii z Koptami (zwanej Decretum pro Iacobitis) ${ }^{8}$. Na jeden fakt należy zwrócić uwagę, a mianowicie na to, że w oficjalnych tekstach Soborów Florenckiego i Trydenckiego nie wprowadzono żadnego kategoryzowania ksiąg świętych - wszystkie są postawione na tym samym poziomie znaczeniowym. Sobór Trydencki, idąc „za przykładem prawowiernych ojców”, precyzuje nawet, że „z jednakową pobożnością i poważaniem przyjmuje oraz czci wszystkie Księgi zarówno Starego, jak i Nowego Testamentu” („pari pietatis affectu ac reverentia”) ${ }^{9}$. Rozróżnienie na księgi protokanoniczne i deuterokanoniczne nie było wówczas jeszcze znane, jednak między wypowiedziami Soborów Florenckiego i Trydenckiego był Marcin Luter (†15 lutego 1546 r.). Zasada sola Scriptura stała się dla niego źródłem wypowiedzi teologicznych oraz inspiracją dla prowadzonej działalności, zwłaszcza dla propagowania Biblii za pośrednictwem opracowanego tłumaczenia i związanej z tym działalności wydawniczej. Pierwsza kompletna Biblia w języku niemieckim opublikowana przez Lutra w 1534 roku opierała się na stanowisku hermeneutycznym i teologicznym sformułowanym przez św. Hieronima, według którego kryterium doboru ksiąg świętych powinna

8 Sobór Florencki, Bulla unii z Koptami Cantate Domino 8,3 - 8,4, w: Dokumenty soborów powszechnych, tekst grecki, łaciński, arabski, ormiański, polski, t. 3: (1414-1445) KonstancjaBazylea-Ferrara-Florencja-Rzym, układ i opracowanie A. Baron, H. Pietras, Kraków 2004, s. 584-587.

9 Sobór Trydencki, Dekret Sacrosancta II, s. 210-211. 
stanowić Hebraica veritas - księgi obce tej tradycji Luter, za Hieronimem, uznawał za apokryfy ${ }^{10}$. Zostały one zamieszczone jako dodatek do Starego Testamentu, a poprzedzało je następujące stwierdzenie: „Księgi, które nie muszą być czczone na równi z Pismem Świętym, chociaż są użyteczne i godne polecenia"11.

Kanon ksiąg biblijnych uznany i ogłoszony przez wspomniane dwa sobory stanie się ostatecznym kryterium doktrynalnym i hermeneutycznym definiującym „Biblię katolicką”. Wcześniejsze dążenia zmierzające do definitywnego określenia takiego wykazu ksiąg biblijnych zostały zatem w pełni i ostatecznie przyjęte. Łączą się one z tymi dążeniami, których świadkiem był zwłaszcza xıı wiek, a które zmierzały do wypracowania jednolitego tekstu biblijnego ${ }^{12}$, chociaż później nadal funkcjonowały jeszcze liczne teksty biblijne $z$ bardzo różnymi wariantami. Wszystko właściwie zostało więc utrwalone, w czym niebagatelną rolę odegrało wynalezienie druku, prowadzące do niejako fizycznego ukonstytuowania się i powszechnego przyjęcia decyzji kanonicznych. Wykaz podany przez Sobór Trydencki jest ostatnim wyrazem dogmatycznym kanonu Pisma Świętego ${ }^{13}$. Jest on sformułowany w sposób autorytatywny - księgi święte są uznane za takie przez Kościół, są w nim przechowywane i przezeń przekazywane. Decydujące znaczenie posiada ich „świętość”, a nie - na przykład - ich jakość literacka. Za takim ujęciem opowiadał się już św. Augustyn. Tekst trydenckiego dekretu Sacrosancta z 8 kwietnia 1546 roku jest bardzo konkretny, a zarazem bardzo jednoznaczny w swoim przesłaniu doktrynalnym. Czytamy w nim: „Jeśli ktoś tych Ksiąg nie przyjmuje jako świętych i kanonicznych w całości, wraz ze wszystkimi ich częściami, tak jak w Kościele katolickim są one czytane i przyjmowane w dawnym wydaniu łacińskim Wulgaty, a wspomnianymi

${ }^{10}$ Por. D. Brown, Vir Trilinguis. A Study of Biblical Exegesis of Saint Jerome, Kampen 1993.

${ }^{11}$ Die Bibel oder die ganze heilige Schrift des Aten und Neuen Testaments nach der deutschen Uebersetzung D. Martin Luters, Teil 2: Die Apokryphen, Berlin 1927, s. 1.

${ }^{12}$ Por. J. Królikowski, Poszukiwania „optymalnego” tekstu Biblii w XIII wieku, „Tarnowskie Studia Teologiczne” 35 (2016) nr 1, s. 133-146.

${ }^{13}$ Warto uwzględnić, że kwestia kanonu jest dzisiaj jednym z bardziej dyskutowanych zagadnień w teologii Pisma Świętego, na które należałoby zwrócić szerszą uwagę także w teologii w Polsce. Por. Les canon des Écritures. Études historiques, exégétiques et systematiques, ed. J.-N. Aletti, Ch. Theobald, Paris 1990; J.-L. Ska, Il libro sigillato e il libro aperto, Bologna 2005, s. 115-164. 
Tradycjami $^{14}$ świadomie i dobrowolnie wzgardzi, niech będzie wyklęty”" Także w tym wypadku zapis dużą literą słowa „Wulgata” nie ma uzasadnienia, gdyż tekst łaciński mówi: „,in veteri vulgata Latina editione”, czyli dosłownie: „W dawnym, rozpowszechnionym, łacińskim wydaniu”. Jak już wspomniano, Wulgata w tamtym czasie jeszcze nie istniała. W każdym jednak razie, Sobór Trydencki jasno i zobowiązująco wypowiedział się na temat kanonu Pisma Świętego. Jego wypowiedź stanowiła odpowiedź na stanowisko zajęte przez Lutra i innych reformatorów, którzy podawali w wątpliwość kanoniczność niektórych ksiąg Starego i Nowego Testamentu' ${ }^{16}$.

Nawet jeśli wprost nie znalazło to odzwierciedlenia w trydenckim dekrecie Sacrosancta, ojcowie na etapie przygotowawczym prowadzącym do zredagowania tego dokumentu wiele dyskutowali o kanoniczności ksiąg biblijnych, o jej zakresie i o jej cechach charakterystycznych, zwłaszcza tych ksiąg, które przez reformatorów były uznawane za apokryficzne (deuterokanoniczne). Dyskusja została zapoczątkowana już dziesięć lat wcześniej przez kard. Kajetana (Tommaso de Vio), eksmistrza generalnego dominikanów, który powołując się na autorytet św. Hieronima opowiadał się za pierwszeństwem tego, co ogólnie określano jako Biblia Hebraica. Według niego wszystkie księgi należą do kanonu, a więc są także kanoniczne, ale pełnią różne funkcje: jedne służą do określenia i utwierdzenia wiary, inne natomiast służą zbudowaniu wiernych. Tak samo mówił wcześniej św. Hieronim. Nie wypowiadając się na ten temat, dekret Sacrosancta nie zamykał drogi teologom, którzy chcieli kontynuować dyskusję o celowości poszczególnych ksiąg biblijnych, dzisiaj powiedzielibyśmy o ich własnym przesłaniu. Jak pokazały dyskusje ojców soborowych, nie chodziło w tym przypadku o jakieś nowe postawienie zagadnienia kanoniczności ani o zrelatywizowanie kanoniczności niektórych ksiąg (Księgi Tobiasza, Judyty, Mądrości, Syracha, Barucha, dodatków do Księgi Daniela oraz do Pierwszej i Drugiej Księgi Machabejskiej), ale o jej adekwatne „zinterpretowanie”. Słynny ówczesny teolog, Girolamo Seripando $(1492-1563)^{17}$, ogłosił krótki traktat De libris

${ }^{14}$ Użycie w tym zdaniu dużej litery w słowie „Tradycje” (łac. traditiones) również nie ma uzasadnienia. Ponadto lepiej byłoby zastosować tutaj słowo „zwyczaje”.

15 Sobór Trydencki, Dekret Sacrosancta I, s. 212-213.

${ }^{16}$ Por. B. Roussel, Des protestants, w: Le temps des Réformes et la Bible, s. 309-326.

${ }_{17}$ Por. H. Jedin, Girolamo Seripando. Sein Leben und Denken im Geisteskampf des 16. Jahrhunderts, Würzburg 1937; Geronimo Seripando e la Chiesa del suo tempo [nel v centenario della nascita]. Atti del convegno di Salerno, 14-16 ottobre 1994, a cura di A. Cestaro, Roma 1997. 
Sacrae Scripturae, w którym dowodził, że w Piśmie Świętym zostały sformułowane canon fidei (kanon wiary) i canon morum (kanon obyczajów). Te dwa „kanony” mogą służyć za kryterium do określenia znaczenia poszczególnych ksiąg biblijnych.

Poglądy Seripanda były często podejmowane i rozwijane. Poszedł za nim między innymi Sisto ze Sieny - Senense (1520-1569), żyd nawrócony na katolicyzm, który przyjął święcenia, wywierając potem duży wpływ swoimi pismami z zakresu biblistyki. Jego dzieło Bibliotheca sancta ex praecibus catholicae Ecclesiae auctoribus collecta (Wenecja 1566) ${ }^{18}$ stanowi jednoznaczną obronę nauczania Soboru Trydenckiego na temat „natchnionego" kanonu, ale przyjmuje zarazem rozróżnienie na dwa „poziomy” (dwie „jakości”) ksiąg będących przedmiotem debaty. W swojej propozycji Sisto ze Sieny idzie jeszcze dalej, a mianowicie w kanonicznym wykazie ksiąg biblijnych wskazuje księgi mające rangę prior, stąd późniejsze określenie „protokanoniczne”, które stało się klasyczne dla katolików. To „pierwszeństwo" nie wynika $z$ autorytetu lub wartości doktrynalnej ksiąg, ale jest związane z czasem ich odkrycia i ich przyjęcia przez Kościół. Druga grupa ksiąg ma rangę posterior - są to księgi, które zostaną następnie nazwane „deuterokanonicznymi”, a Sisto zamieścił ich pełną listę.

Kanon Soboru Trydenckiego został w pełni uszanowany, chociaż był interpretowany w relacji do różnego celu ksiąg, które w całości pozostają kanoniczne. W przyszłości wszystkie „introdukcje biblijne” bardzo wyraźnie przychylą się do tego stanowiska i będą podkreślać, że poszczególne księgi różnią się ich własną celowością i ich własnym przesłaniem teologicznym. Zagadnienie to zachowuje znaczenie do dnia dzisiejszego w studiach biblijnych, w których jedną z pierwszych analizowanych rzeczy, jest cel napisania takiej czy innej księgi biblijnej. Różnice w podejściu do wykazu ksiąg biblijnych będą odtąd właściwie dotyczyć poszczególnych wyznań chrześcijańskich. Protestanci nie uznają za kanoniczne ksiąg „deuterokanonicznych", nazywając je apokryfami. Dla prawosławnych właściwym tekstem biblijnym Starego Testamentu jest Septuaginta; wykaz zawartych tam ksiąg nie pokrywa się w pełni z wykazem ksiąg podanym przez Sobory Florencki i Trydencki.

${ }^{18}$ Księga v tego dzieła była publikowana osobno pod tytułem Ars interpretandi Sacras Scripturas (Kolonia 1577). Dzieło Sykstusa ze Sieny może być uważane za pierwszą nowożytną „introdukcję biblijną". 


\section{Długa droga do Wulgaty}

Zajmując się kanonem ksiąg biblijnych, Sobór Trydencki podjął także kwestię właściwego tekstu tychże ksiąg ${ }^{19}$. Zagadnienie łacińskiej wersji Biblii zostało podjęte już w czasie pierwszych posiedzeń ekspertów soborowych w marcu 1546 roku. Byli oni świadomi istnienia „nadużyć” spowodowanych wielością wydań Biblii i niemal nieskończoną liczbą wariantów w tekstach poszczególnych ksiąg. Pojawiało się więc zasadnicze pytanie, którą wersję Biblii należało uwzględnić i zatwierdzić do „powszechnego” użytku w Kościele? Odpowiedź zakładała jako bezpośredni skutek wskazanie tekstu, który byłby możliwie najbardziej poprawny. Dekret Sacrosancta nic jednak nie mówi na ten temat, chociaż zdaje się zakładać taką potrzebę. Na zgromadzeniu ogólnym w dniu 17 marca został przedstawiony pierwszy projekt w tej materii, w którym jako pierwsze „nadużycie” zidentyfikowano funkcjonowanie wielu wydań Biblii: „Pierwsze nadużycie polega na tym, że istnieją różne wydania Pisma Świętego i chce się je używać jako autentyczne w nauczaniu publicznym, w dyskusjach i w przepowiadaniu. Remedium polega na posiadaniu jednego wydania, to znaczy starożytnego i rozpowszechnionego (vetus et vulgata), z którego jako autentycznego wszyscy będą korzystać w wykładach publicznych, w dyskusjach, w komentarzach i w przepowiadaniu oraz którego nikt nie ośmieli się odrzucać lub mu sprzeciwiać, nie ujmując jednak niczego autorytetowi czystej i autentycznej tradycji Septuaginty, którą w pewnym okresie posługiwali się apostołowie, a także nie odrzucając innych wydań, w takiej mierze, w jakiej pomagają nam zrozumieć to autentyczne i rozpowszechnione wydanie"20.

Autorzy wyrażali swoje rozgoryczenie z powodu zmian wprowadzanych do funkcjonującej vulgata editio. Poprawne i przejrzane wydanie nie było więc tylko godnym uwagi postulatem, ale stało się pilną potrzebą i dlatego należało zwrócić się do papieża z prośbą o realizację takiego dzieła. Podkreślono również potrzebę poprawnego wydania tekstów oryginalnych, hebrajskich i greckich. Nie powiedziano jednak niczego na temat św. Hieronima i jego tłumaczenia Biblii. Zalecano, aby Kościół dokonał ekskluzywnego wyboru Biblii łacińskiej, dla którego podstawę stanowiło tłumaczenie ex Hebreo,

19 Por. G.-M. Vosté, J.-M. Vosté, La Volgata al Concilio di Trento, „Biblica” 27 (1946) no. 4, s. 301-319.

${ }^{20}$ G.-M. Vosté, J.-M. Vosté, La Volgata al Concilio di Trento, s. 309. 
ażeby potem ta Biblia mogła służyć za podstawę nauczania doktrynalnego, dyskursu teologicznego, lektury publicznej, a zwłaszcza by mogła zostać wykorzystana w liturgii. W pierwszej fazie soboru, między marcem a czerwcem 1546 roku, można odnotować wielość zajmowanych przez ojców stanowisk. Kardynał Cristoforo Madruzzo (1512-1578), biskup Trydentu, zaproponował, na przykład, wydanie tekstu „autentycznego”, trochę jakby Biblii łacińskiej vetus et vulgata, ale w języku każdego narodu (in unoquoque idiomate). Inni proponowali odrzucenie każdej innej wersji jako będącej źródłem herezji, $\mathrm{z}$ wyjątkiem vulgata editio. Ojcowie soborowi podzielili się na dwie frakcje, aż $\mathrm{w}$ końcu w prowadzonych dyskusjach dojrzała propozycja pośrednia. Zrezygnowano z tłumaczeń na języki różnych narodów i opowiedziano się za autentycznością vulgata editio, przypisując jej prymat prawny i faktyczny w zastosowaniu kościelnym. Dekret Sacrosancta, zatwierdzony jednogłośnie w dniu 5 kwietnia, a promulgowany 8 kwietnia, idzie w tym kierunku, wyjaśniając i stanowiąc: „Ponadto święty synod, biorąc pod uwagę, że może być nader korzystnym dla Kościoła Bożego, jeżeli któreś spośród wszystkich wydań łacińskich obejmujących święte Księgi będzie uważane za autentyczne (authentica), postanawia i wyjaśnia, aby to stare i powszechnie uznane wydanie (vetus et vulgata editio), które będąc w użyciu przez tyle stuleci zdobyło sobie uznanie w Kościele, było traktowane jako autentyczne w nauczaniu publicznym, w dysputach, kazaniach i wykładach, a także by nikt nie ważył się ani nie ośmielał, pod żadnym pozorem, go odrzucać” ${ }^{21}$.

Sobór polecił następnie, aby Pismo Święte, przede wszystkim vetus et vulgata editio, było drukowane z największą starannością. Papież Paweł III, po otrzymanych wyjaśnieniach dostarczonych przez jego teologów za pośrednictwem legatów papieskich, zatwierdził dekret. Podstawowym zamiarem było dostarczenie Kościołowi rzymskiemu oficjalnego tekstu ksiąg świętych, który nie byłby kontestowany i mógłby być powszechnie używany w Kościele. Była to bezwarunkowa konieczność. Z punktu widzenia krytycznego i literackiego zaaprobowana i wykorzystywana wersja była uważana za niedoskonałą; nie była stawiana ponad tekstami oryginalnymi, to znaczy hebrajskim i greckim, ani ponad tłumaczeniami łacińskimi i innymi uznanymi za „starożytne”, zwłaszcza tymi, którymi od dłuższego czasu posługiwały się Kościoły wschodnie. Prawo do odwołania się do tekstów oryginalnych i do wersji starożytnych zostało uznane w sposób pośredni. Sobór czynił

${ }^{21}$ Sobór Trydencki, Dekret Sacrosancta II, s. 212-213. 
z vulgata editio za pośrednictwem aktu dogmatycznego dokument publiczny i oficjalny, którego nikt nie mógł odrzucać w określonych sytuacjach. Zastosował on przymiotnik ,autentyczny” w sensie prawnym, a więc takim, jaki prawnicy i kanoniści nadawali mu w tamtym czasie ${ }^{22}$. Zastosowane pojęcia były bardzo wyważone, ale zarazem bardzo precyzyjne, nawet jeśli po soborze stały się przedmiotem wielu ożywionych dyskusji, zwłaszcza wśród teologów, którzy nie brali w nim udziału. Wśród katolików nie brakowało również takich, którzy trydencki przymiotnik authenticus interpretowali w sposób jednoznacznie wyłączny i zacieśniający, a więc w sensie „ten i tylko ten”. Takie stanowisko reprezentował na przykład Domingo Báñez (1528-1604), słynny teolog z Salamanki.

Ojcowie Soboru Trydenckiego byli świadomi, że istnieje wiele egzemplarzy tekstu biblijnego uważanych za autentyczne. Nie wiadomo, jak odnosili się do tego zjawiska, gdyż wyrażali się w sposób bardzo ogólny. Nie wskazali oni żadnej konkretnej Biblii, która mogłaby być uznana za „wzorcową” („prototyp”), a stwierdzenie vetus et vulgata editio z dekretu soborowego nie odnosiło się do żadnego konkretnego wydania. Zwrócili się do papieża, aby podjął starania o wydanie Pisma Świętego, którego tekst byłby możliwie najbardziej poprawny. W swojej wypowiedzi autorzy dekretu dawali głównie wyraz trosce o staranność druku, tymczasem teologowie rzymscy zauważyli, że problem ma o wiele szerszy zasięg. Podkreślili więc, że trzeba najpierw ustalić, który tekst naddaje się do druku, nosząc wyraźnie znamiona „wzorczości”. Podjęto zatem prace zmierzające do wprowadzenia korekt w tekście biblijnym i zrewidowania go w celu przygotowania oczekiwanego wydania. Prace zostały zapoczątkowane już w 1546 roku, ale jeszcze w 1554 były in statu fieri.

Papież Pius IV powołał więc komitet złożony z kardynałów i ekspertów, który podjął zlecone mu prace. W grudniu 1563 roku zakończył się sobór trydencki, lecz przedsięwzięcie nadal nie było doprowadzone do końca. Papież Pius v zatwierdził na nowo komitet powołany przez jego poprzednika, dokonując jego poszerzenia, co jednak nie przyspieszyło prac. W drugim roku pontyfikatu (1586 r.) Sykstus v na nowo zajął się tą sprawą.

${ }^{22}$ Rozumienie tego określenia dobrze wyjaśnił Robert Bellarmin w mało znanej rozprawie na ten temat. Por. R. Bellarmin, De editione Latina vulgata, quo sensu a Concilio Tridentino definitum sit, ut pro authentica habemus, w: X.-M. Le Bechelet, Bellarmin et la Bible sixto-clémentine. Étude et documents inédits, Paris 1911, s. 107-125. 
Przywieziono do Rzymu najlepsze manuskrypty z różnych bibliotek Italii, Hiszpanii i Flandrii, które stały się przedmiotem rozbudowanych analiz. Praca została doprowadzona do końca w ciągu dwóch lat i przedstawiona papieżowi na początku 1589 roku. Sykstus v skrupulatnie przeczytał tekst, nanosząc także własne poprawki i polecając wydanie tekstu na mocy bulli Aeternus Ille (1 marca 1590 r.). Chciał również bezpośrednio czuwać nad drukiem, dlatego został on wykonany w Watykanie, a ukończony 10 kwietnia 1590 roku. Drukowana Biblia nosiła tytuł Biblia sacra vulgatae editionis ad concilii Tridentini praescriptum emendata a Sixto V P. M. recognita et approbata. U schyłku życia papież myślał jeszcze o wydrukowaniu czegoś w rodzaju correctorium noszącego jego imię, ale przeszkodziła mu w tym śmierć, która nastąpiła 27 sierpnia 1590 roku.

Pod adresem opublikowanej Biblii podniosły się wówczas głosy krytyczne, formułowane przez członków komitetu. Nie znalazły uznania korekty, które papież wprowadził do opracowanego przez nich tekstu. W okresie sede vacante kardynałowie, którzy zajmowali się administracją kościelną, wstrzymali sprzedaż Biblii Sykstusa v. To wydanie nie było pozbawione wartości krytycznej, również poprawki wprowadzone przez Sykstusa v były do przyjęcia - była to Biblia, która w pełni mogła być uznana za rezultat poważnej i krytycznej pracy naukowej. Mimo to już w lutym 1591 roku nowy papież - Grzegorz XIV - powierzył Kongregacji Indeksu zadanie dokonania rewizji tekstu Biblii. Śmierć papieża Grzegorza XIV w dniu 16 października tego roku, a potem Innocentego Ix (papież od 29 października do 30 grudnia tegoż roku), nie sprzyjała szybkiemu kontynuowaniu prac nad edycją Biblii. Do sprawy powrócił Klemens viII, który został wybrany 30 stycznia 1592 roku. Aprobując komitet wyłoniony przez papieża Grzegorza xıv, Klemens viI zlecił wprost dwom kardynałom i jednemu ekspertowi (który sam zresztą wykonał tę pracę), przygotowanie tekstu do druku. Był on gotowy 28 sierpnia tego samego roku. Bullą Cum Sacrorum ogłoszoną 9 listopada 1592 roku nowa Biblia została zatwierdzona do druku. Pojawiła się ona w bardzo krótkim czasie, jeszcze przed końcem roku. Był to piękny wolumin in folio, drukowany w Watykanie, sygnowany imieniem Sykstusa $\mathrm{v}^{23}$ (imię Klemensa viII zostanie dodane dopiero w 1604 roku).

${ }^{23}$ Wydaje się, że nie są uzasadnione stwierdzenia Bardskiego, według którego Bellarmin „edycję sykstyńską [Biblii] nazwał jednym z największych skandali w Kościele katolickim” (K. Bardski, Wulgata, kol. 1029). 
Szczególną rolę w tym przedsięwzięciu odegrał wskazany przez papieża Robert Bellarmin (1542-1621), teolog jezuicki, który potem został ogłoszony kardynałem i pełnił znaczące funkcje kościelne w okresie reformy katolic$k^{2} j^{24}$. Na jego wniosek papież Klemens viII polecił w 1592 roku odkupić egzemplarze poprzedniej edycji pozostające jeszcze w obiegu, choć korzystanie z niej nie było zakazane. Zdecydowano, że nowe wydanie nie będzie jednak przeszkadzać w sprzedaży starych egzemplarzy, chociaż biorąc pod uwagę, że zachowało się niewiele egzemplarzy Biblii Sykstusa v, można sądzić, że sprzedaży faktycznie nie prowadzono. Niebawem, w roku 1593 i 1598, pojawiły się kolejne wydania nowego tekstu Biblii. Bellarmin skierował do czytelnika wprowadzenie, w którym stwierdzał, że nowe wydanie jest w pełni zgodne z wcześniejszym zamysłem papieża Sykstusa v, który zresztą sam nie był zachwycony Biblią drukowaną pod jego kierunkiem: „qui nunc Ecclesiae universae gubernacula tenet, opus, in quod Sixtus v intenderat, Deo bene iuvante, perfectum est" 25 .

Klemens viII zagwarantował drukarni watykańskiej monopol na drukowanie Biblii na dziesięć lat, prawdopodobnie mając na względzie rozpowszechnienie tekstu, który byłby wolny od ewentualnych modyfikacji wprowadzanych arbitralnie przez innych wydawców, a tym samym, by „autentyczność" przygotowanego tekstu mogła zostać wystarczająco utrwalona.

W tym miejscu należy zauważyć, że dopiero po opublikowaniu trzech wydań z tytułem Biblia Sacra vulgatae editionis, formuła vulgata editio (także pisana dużymi literami w sensie rzeczownikowym jako nazwa własna) została włączona do tytułów wszystkich Biblii łacińskich, które posiadały imprimatur udzielony w Rzymie. Do połowy xx wieku Biblia, nazywana Syksto-Klementyńską, będzie oficjalnym tekstem Pisma Świętego Kościoła rzymskiego w sytuacjach i w okolicznościach określonych przez dekret Sacrosancta Soboru Trydenckiego.

Jeśli natomiast chodzi o św. Hieronima, to trzeba powiedzieć, że w Biblii Syksto-Klementyńskiej wykorzystano jego tłumaczenie, ale nie tylko - skorzystano także z innych starożytnych tłumaczeń Pisma Świętego, starając się przygotować tekst, który byłby w pewnym sensie wypadkową łacińskiej

${ }^{24}$ Por. Bellarmino e la Controriforma. Atti del Simposio internazionale di studi. Sora, 1518 ottobre 1986, a cura di R. De Maio, Sora 1990.

${ }_{25}$ [R. Bellarmin], Praefatio ad lectorem, w: Bibliorum Sacrorum iuxta Vulgatam Clementinam nova editio, curavit A. Gramatica, Typis Polyglottis Vaticanis MCMXXIX, s. XIII. 
tradycji biblijnej. Ilustruje to dobrze wypowiedź Bellarmina ze wspomnianej już przedmowy: „Qui namque in ea libri continentur (ut a maioribus nostris quasi per manus traditum nobis est) partim ex sancti Hieronymi translatione vel emendatione suscepti sunt, partim retenti ex antiquissima quadam editione latina, quam sanctus Hieronymus communem et vulgatam, sanctus Augustinus Italam, sanctus Gregorius veterem translationem appellat” ${ }^{26}$. Wersja św. Hieronima stanowi tylko partim nowej wersji Biblii, a więc została „częściowo” do niej włączona. Są także inne źródła (partim), zwłaszcza stara, przedhieronimowa wersja łacińska, z której korzystano, opracowując tekst Biblii, i to właśnie tej wersji św. Hieronim nadaje miano communis et vulgata. Ten stosunkowo prosty fakt nie pozwala na to, by mówić o Wulgacie jako dziele św. Hieronima, ponieważ jest to, wprawdzie dominujące, ale tylko jedno ze źródeł Biblii Syksto-Klementyńskiej, czyli późniejszej Wulgaty.

Biblia papieża Klemensa vıı nie ograniczała się do ksiąg świętych, które wymienił dekret Sacrosancta z 1546 roku. W apendyksie dodano Modlitwę Manasesa oraz Trzecią i Czwartą Księge Machabejską. Biblia papieża Sykstusa v nie uwzględniała tych ksiąg; zostały one również opuszczone w tłumaczeniach Wulgaty na języki narodowe, chociaż nadal pozostawały w wydaniach łacińskich. Protestanci zdecydowanie krytykowali wydania Biblii opracowane pod patronatem papieży, mimo że wydanie zatwierdzone przez Klemensa viı było oparte na poważnym wysiłku połączonym z wykorzystaniem kryteriów naukowych tamtego czasu. W znacznym stopniu poprawiało ono wersję zatwierdzoną przez papieża Sykstusa v.

W XVII i XVIII wieku wydania Wulgaty (i dopiero od tego czasu to określenie może być traktowane jako nazwa własna) były bardzo liczne. Na ogół odzwierciedlały one wcześniejsze wydania, przede wszystkim kluczowe wydanie z 1598 roku, które zawierało potrójną erratę. W XIX i xx wieku byli wydawcy, którzy publikowali poprawione wersje Wulgaty. Barnabita Carlo Vercellone (1814-1869), zachęcony przez papieża Piusa IX, zebrał warianty do przyszłej korekty oficjalnej Wulgaty i opublikował dwa ogromne tomy (1860 i 1864) zatytułowane Variae lectiones Vulgatae Latinae Bibliorum editionis. Jest to monumentalnie dzieło, które nie zostało jednak ukończone $\mathrm{z}$ powodu śmierci autora.

${ }^{26}$ [R. Bellarmin], Praefatio ad lectorem, s. XII. 
Papież Pius x przyczynił się do kontynuowania dzieła korekty Wulgaty, w 1907 roku powierzając to zadanie benedyktynom. Pracowali oni nad wydaniem krytycznym, które zostało zapoczątkowane w 1926 roku od wydania Księgi Rodzaju. Papież Pius XI mocno zinstytucjonalizował i wsparł te działania, erygując w Rzymie Opactwo św. Hieronima, w którym miano systematycznie kontynuować to dzieło przy wydatnym wsparciu Stolicy Apostolskiej ${ }^{27}$. Doczekało się ono szczęśliwego końca jako Biblia sacra iuxta Latinam Vulgatam versionem ad codicum fidem (Roma 1926-1987).

Po II soborze watykańskim papież Paweł vi powierzył komisji papieskiej zadanie przygotowania nowego tłumaczenia łacińskiego Biblii, uwzględniającego najnowsze osiągnięcia badań biblijnych. Po długim okresie prac, wykorzystując zwłaszcza osiągnięcia biblistów zgromadzonych wokół Opactwa św. Hieronima w Rzymie, nowe tłumaczenie łacińskie Biblii zostało zatwierdzone przez papieża Jana Pawła II i opublikowane pod tytułem Nova Vulgata Bibliorum Sacrorum Editio. Sacrosancti oecumenici concilii Vaticani II ratione habita iussu Pauli PP. VI recognita auctoritate Ioannis Pauli PP. II promulgata. Na ogół nazywa się tę wersję Biblii łacińskiej „Neo-Wul-

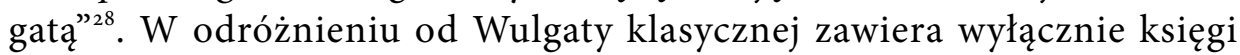
kanonu ogłoszonego przez Sobór Trydencki ${ }^{29}$.

Promulgując Neo-Wulgatę, papież Jan Paweł II podkreślił, że jest to tekst „przeznaczony zwłaszcza do użytku w świętej liturgii, lecz przystosowany także [...] do innych celów"30. Chodzi zwłaszcza o cele duszpasterskie i duchowe, które mają bardzo bezpośredni związek z tradycyjnym łacińskim tekstem Biblii, choćby $\mathrm{z}$ tego powodu, że cała tradycja kościelna $\mathrm{w}$ tych dziedzinach opiera się na nim, często nawet na jego rozmaitych wariantach. Niestety, zapoczątkowana w Polsce publikacja nowej wersji lekcjonarza mszalnego nie uwzględnia tego wskazania papieskiego, jak i późniejszej normy wydanej przez Kongregację ds. Sakramentów i Kultu Bożego, według

${ }_{27}$ Por. Pius PP. XI, Constitutio apostolica Inter praecipuas (15.06.1934), „Acta Apostolicae Sedis" [dalej: AAs] 26 (1934), s. 85-87.

${ }^{28}$ Przyjmuje się również pisownię „Neowulgata”.

${ }_{29}$ Por. K. Bardski, Neo-Wulgata a tłumaczenie św. Hieronima, w: Ioannes Paulus - in memoriam. Księga pamiątkowa Stowarzyszenia Biblistów Polskich ku czci Ojca Świętego Jana Pawła II, red. W. Chrostowski, Warszawa 2006, s. 15-26.

${ }^{30}$ Ioannes Paulus II, Constitutio apostolica Scripturarum thesaurus (25.04.1979), AAS 71 (1979), s. 559. Tłumaczenie polskie według: Jan Paweł II, Dzieła zebrane, t. 2, Kraków 2007, s. 33 . 
której w przygotowaniu czytań mszalnych należy opierać się na wydaniu Biblii łacińskiej, zatwierdzonej przez papieża Jana Pawła II, czyli na Neo-Wulgacie ${ }^{31}$. Jakkolwiek Biblia Tysiąclecia osiągnęła także pewną rangę liturgiczną, to jednak wykorzystanie jej w lekcjonarzu jawi się jako dalece niewystarczające, a w niektórych przypadkach jest po prostu ułomne. Najbardziej razi rozdźwięk między tekstami liturgicznymi i tekstami biblijnymi. Zagadnienie to zasługuje jednak na osobne potraktowanie w kontekście liturgicznym, dlatego nie będziemy go tutaj rozwijać.

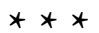

Za podsumowanie niech nam posłuży niezwykle trafna uwaga na temat Wulgaty, którą znajdujemy w biblijnych refleksjach Paula Claudela, wielkiego miłośnika tej wersji Pisma Świętego, na której zbudował zasadniczą część swojej twórczości poetyckiej i wrażliwości duchowej: „W Wulgacie [...] posiadamy tłumaczenie ksiąg świętych będące poetyckim pomnikiem, które osobiście uważam za arcydzieło łacińskiego języka. Jeśli nie jest natchniona w sensie teologicznym, to na pewno jest natchniona w sensie literackim. [...] Racją istnienia, jaką od wieków daje nam Wulgata, jest to, że stanowi zarówno dla świętych, jak i dla grzeszników niewyczerpane źródło nauki, entuzjazmu, pociechy i oświecenia, czegoś, co - jak Eucharystia - jest korzeniem raju, językiem w naszych spotkaniach z Bogiem" ${ }^{\prime 2}$. A nieco dalej wskazuje na właściwą postawę, która powinna towarzyszyć korzystaniu z Wulgaty: „Czytajmy więc Wulgatę i czytajmy ją tak, jak powinniśmy ją czytać - na kolanach" ${ }^{33}$. Można dodać, czytajmy ją wszyscy, mając oczywiście w pamięci długą drogę duchową i teologiczną, która doprowadziła do jej powstania oraz racje, które przyczyniły się do jej utrwalenia w życiu i tradycji Kościoła katolickiego.

${ }^{31}$ Por. Congregatio de Cultu Divino et Disciplina Sacramentorum, Decretum Ordo lectionum missae (21.01.1981), w: Enchiridion Biblicum. Documenti della Chiesa sulla Sacra Scrittura, Bologna 1993, s. 798-801 (nr 775-776).

${ }^{32}$ P. Claudel, Umiłowanie Pisma Świętego, tłum. P. Lubicz, Warszawa 1958, s. 74-75.

33 P. Claudel, Umiłowanie Pisma Świętego, s. 76. 


\section{Bibliografia}

Bardski K., Neo-Wulgata a tłumaczenie św. Hieronima, w: Ioannes Paulus - in memoriam. Księga pamiątkowa Stowarzyszenia Biblistów Polskich ku czci Ojca Świętego Jana Pawła II, red. W. Chrostowski, Warszawa 2006, s. 15-26.

Bardski K., Wulgata, w: Encyklopedia katolicka, red. E. Giglewicz, t. 20, Lublin 2014, kol. 1027-1030.

Bechelet X.-M. Le, Bellarmin et la Bible sixto-clémentine. Étude et documents inédits, Paris 1911.

Bedouelle G., La Réforme catholique, w: Le temps des Réformes et la Bible, dir. G. Bedouelle, B. Roussel, Paris 1989, s. 327-367.

Bellarmino e la Controriforma. Atti del Simposio internazionale di studi. Sora, 15-18 ottobre 1986, a cura di R. De Maio, Sora 1990.

Brown D., Vir Trilinguis. A Study of Biblical Exegesis of Saint Jerome, Kampen 1993. Claudel P., Umiłowanie Pisma Świętego, tłum. P. Lubicz, Warszawa 1958.

Dokumenty soborów powszechnych, tekst grecki, łaciński, arabski, ormiański, polski, t. 3: (1414-1445) Konstancja-Bazylea-Ferrara-Florencja-Rzym, układ i opracowanie A. Baron, H. Pietras, Kraków 2004.

Dokumenty soborów powszechnych, tekst łaciński, polski, t. 4/1: (1511-187o) Lateran VTrydent-Watykan I, układ i opracowanie A. Baron, H. Pietras, Kraków 2004.

Enchiridion Biblicum. Documenti della Chiesa sulla Sacra Scrittura, Bologna 1993. Geronimo Seripando e la Chiesa del suo tempo [nel v centenario della nascita]. Atti del convegno di Salerno, 14-16 ottobre 1994, a cura di A. Cestaro, Roma 1997.

Ioannes Paulus II, Constitutio apostolica Scripturarum thesaurus (25.04.1979), „Acta Apostolicae Sedis" 71 (1979), s. 557-559.

Jedin H., Girolamo Seripando. Sein Leben und Denken im Geisteskampf des 16. Jahrhunderts, Würzburg 1937.

Królikowski J., Poszukiwania „optymalnego” tekstu Biblii w XIII wieku, „Tarnowskie Studia Teologiczne" 35 (2016) nr 1, s. 133-146.

Les canon des Écritures. Études historiques, exégétiques et systematiques, ed. J.-N. Aletti, Ch. Theobald, Paris 1990.

Pius PP. XI, Constitutio apostolica Inter praecipuas (15.06.1934), „Acta Apostolicae Sedis" 26 (1934), s. 85-87.

Roussel B., Des protestants, w: Le temps des Réformes et la Bible, dir. G. Bedouelle, B. Roussel, Paris 1989, s. 309-326.

Ska J.-L., Il libro sigillato e il libro aperto, Bologna 2005. 
Vaccari A., Esegesi ed esegeti al Concilio di Trento, „Biblica” 27 (1946) no. 4, s. 320-337. Vosté G.-M., Vosté J.-M., La Volgata al Concilio di Trento, „Biblica” 27 (1946) no. 4, s. 301-319.

\section{Streszczenie}

Wulgata jest łacińskim tłumaczeniem Biblii, któremu przypisywano wielkie znaczenie w Kościele i który nadal jest uznawany za wzniosły tekst, zwłaszcza w liturgii. Istnieje jednak wiele nieporozumień dotyczących Wulgaty i w konsekwencji zdarza się, że niektóre łacińskie tłumaczenia Biblii odnoszą się do Wulgaty, podczas gdy są zupełnie odmiennymi tekstami. Ten artykuł jest próbą wyjaśnienia, jakie były początki Wulgaty jako autentycznego tekstu Biblii po soborze trydenckim i jak to przekonanie zostało zachowane w życiu i tradycji Kościoła katolickiego.

\section{Słowa kluczowe}

Biblia, Wulgata, sobór trydencki

\section{Summary}

The Origins of the Vulgate and the Correct Application of the Term The Vulgate is a Latin translation of the Bible, which has been considered to be of great importance for the Church and which is continuingly regarded as the superior text, especially in the liturgy. However, there are many misunderstandings relating to the Vulgate and as a consequence it happens that certain Latin translations of the Bible are refer to as the Vulgate while they are completely different texts. This article is an attempt to explain what were the origins of the Vulgate as an authentic text of the Bible after the Council of Trent and how it was preserved in the life and tradition of the Catholic Church.

\section{Keywords}

Bible, Vulgate, Council of Trent 